Page 1 of $2 \quad$ Proj.

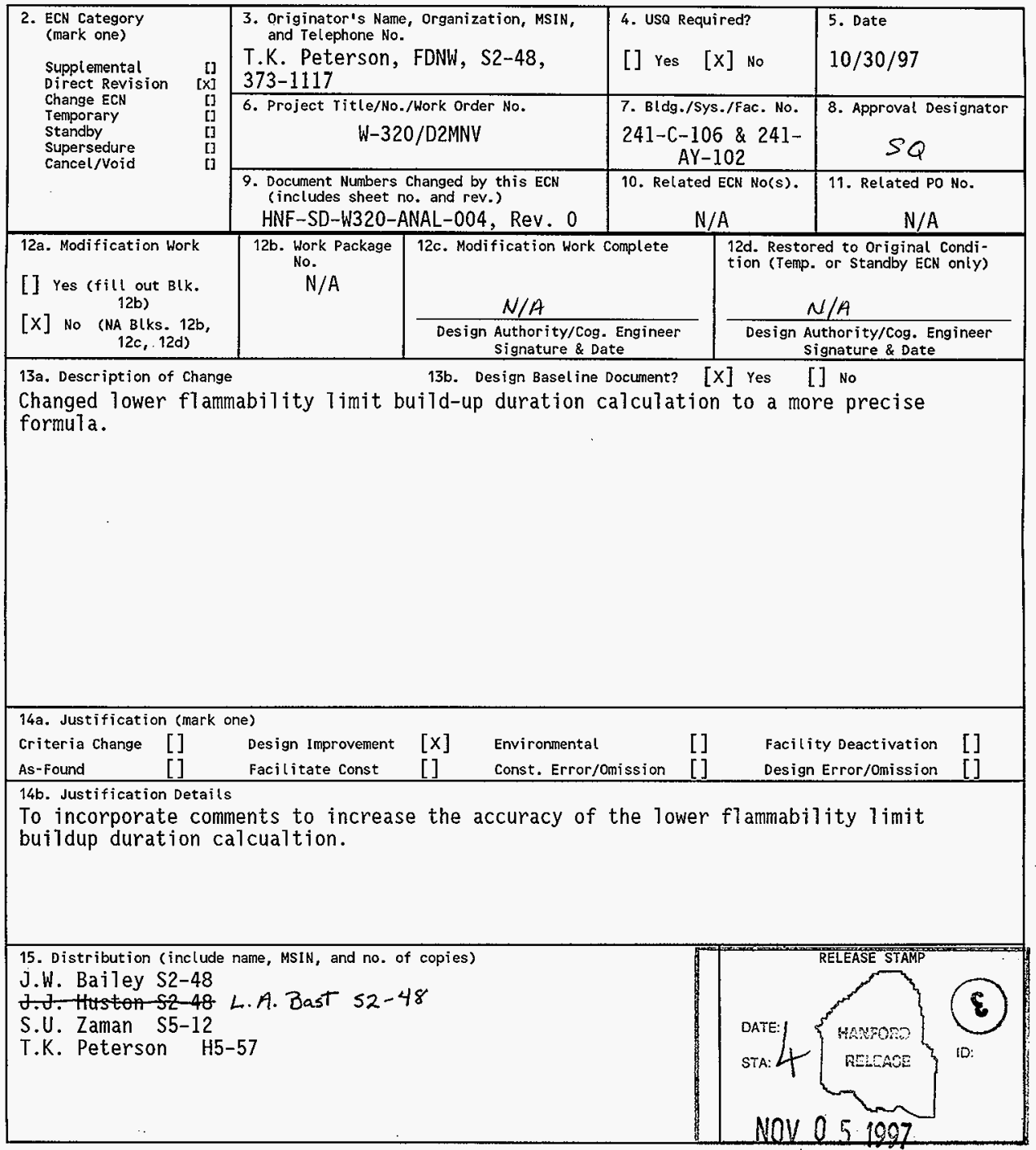




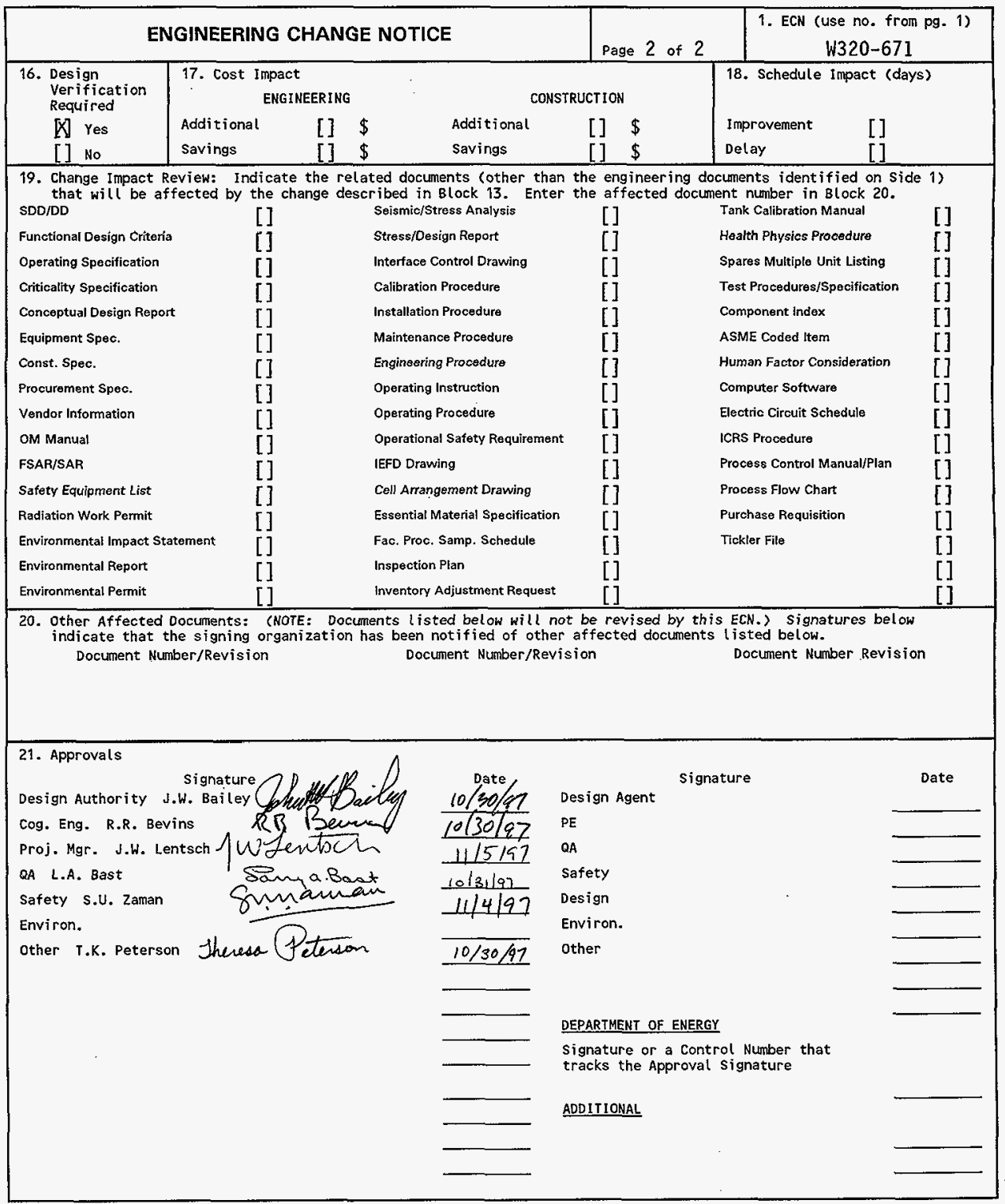




\title{
W-320 Waste Retrieval Sluicing System Transfer Line Flushing Volume and Frequency Calculation
}

\author{
J.W. Bailey \\ Numatec Hanford Corporation, Richland, WA 99352
}

U.S. Department of Energy Contract DE-AC06-96RL.13200

$\begin{array}{lll}\text { EDT/ECN: } & \text { W320-671 } & \text { UC: } 510 \\ \text { Org Code: } & \text { UC200000 } & \text { Charge Code: D2MNV } \\ \text { B\&R Code: } & \text { EW3130010 } & \text { Tota1 Pages: } 8\end{array}$

Key Words: Transfer Line, Pipe Line, Flushing, W-320, Waste Retrieval Sluicing System, WRSS, Routine Flushing

Abstract: The clculations contained in this analysis document establish the technical basis for the volume, frequency, and flushing fluid to be utilized for routine Waste Retrieval Sluicing System (WRSS) process line flushes. The WRSS was installed by Project $W-320$, Tank 241-C-106 sluicing. The double contained pipelines being flushed have $4^{\prime \prime}$ stainless steel primary pipes.

The flushes are intended to prevent hydrogen build up in the transfer lines and to provide ALARA conditions for maintenance personnel.

TRADEMARK DISCLAIMER. Reference herein to any specific comercial product, process, or service by trade name, trademark, manufacturer, or otherwise, does not necessarily constitute or imply its endorsement, recommendation, or favoring by the United states Government or any agency thereof or its contractors or subcontractors.

Printed in the United States of America. To obtain copies of this document, contact: Document Control Services, P.0. Box 950, Mailstop H6-08, Richland WA 99352, Phone (509) 372-2420; Fax (509) 376-4989.
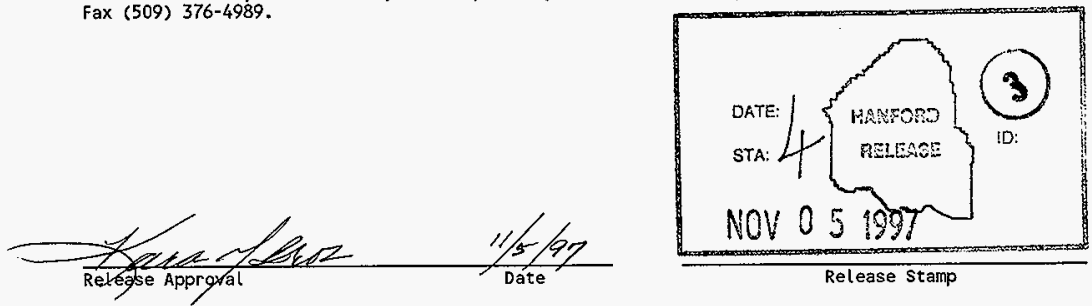
(2) Title

W-320 Waste Retrieval Sluicing System Transfer Line Flushing Volume and Frequency

Calculation

CHANGE CONTROL RECORD

\begin{tabular}{l|l} 
(3) Reyision & EDT-6010588 \\
\hline 1 RS & $\begin{array}{l}\text { Replace page 3. Revise the formula } \\
\text { for the LFL Build-up Duration with the } \\
\text { exponential concentration replacing } \\
\text { the approximation formula }\end{array}$ \\
& (ECN $1320-671)$
\end{tabular}

Authorized for Release

(5) Cog. Engr. (6) Cog. Mgr. Date

J.W. Bailey J.W. Lentsch

W. W/5k7

dud fewh the approximation formula (atcin

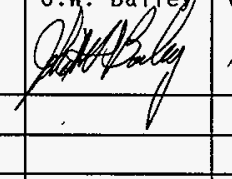


HNF-SD-W320-ANAL-004, Rev. 1

\section{W-320 WASTE RETRIEVAL SLUICING SYSTEM TRANSFER LINE FLUSHING VOLUME AND FREQUENCY CALCULATION}

OBJECTIVE / PURPOSE - This calculation is performed to establish a basis for the volume of flush solution, the frequency of flushes of the Waste Retrieval Sluicing System (WRSS) slurry and supernate transfer lines to prevent the buildup of flammable levels of hydrogen in the transfer lines, and the appropriate type of flush solution.

\section{OPEN ITEMS - None.}

METHODS OF ANALYSIS - In this section, a number of design inputs are utilized these are discussed further and source references are provided in the design inputs section of this calculation document.

Flush Volume Calculation - This calculation involved a combination of a calculation of the line volume in gallons using the straight forward volume equation, below and a rationale for the number of line volumes required to accomplish an adequate flush.

Line Volume Equation -

PIPELINE VOLUME $=\left(\pi \mathrm{r}^{2} \mathrm{~L}\right) *\left(7.5\right.$ gal. $\left./ \mathrm{ft}^{3}\right)$

Where: $\quad r=$ Pipe Radius

$\mathrm{L}=$ Pipeline Length

Flush Volume Calculation -

$(3.14) *(0.165) *(0.165) *(1730) *(7.5)=1,109$ gallons

Adding 90 gallon allowance for jumper \& equipment volumes $=1,200 \mathrm{Gal}$.

TOTAL FLUSH VOLUME, Therefore $=(2) *(1,200$ gal. $)=2,400$ gallons

Number of Pipeline Volumes Required Rationale - The basis or rationale for selecting two pipeline volumes involves the fact that the pipeline must be filled with fluid before adequate flushing is achieved. This is true because gutter flow conditions will be present in the pipe until the main restrictions in the piping system are encountered. These restrictions are located at the C Farm end of the pipelines, ie., the sluicer nozzle for the sluice line and the booster and immersible pump impellers for the slurry line.. Filling the pipeline does not, therefore, occur until at least one pipe volume of flushing solution has entered and fills the line. Introduction of the second pipe volume of solution forces the first volume out at a flow rate which is in transition zone, non-laminar flow realm and should provide adequate solids 
HNF-SD-W320-ANAL-004, Rev. 1

resuspension and removal. When the flush is terminated, the second line volume then gravity drains out of the pipe not producing any significant additional solids removal.

Flushing Frequency Calculation - This calculation involved a combination of three calculations:

1. Calculation of the volume (gallons) of solids left in the transfer line after an unplanned shutdown of the pumping system with the solids loading at the highest allowed value in gallons. With a starting point of $30 \%$ solids loading, the time required for the line to drain, and the solids settling rate the percent of the solids which will be left in the line is calculated.

Maximum Transfer Line Solids Volume @ Pump Shutdown - Is equal to the transfer line volume times $30 \%$ solids loading.

$$
(1,200 \text { gal. }) *(0.30)=\mathbf{3 6 0} \text { gallons }
$$

Percentage of Solids Settled During Transfer Line Drain Back - Is approximately equal to the solids settling rate $(0.45 \mathrm{~cm} / \mathrm{min}$ or $0.177 \mathrm{in} / \mathrm{min}$.) times the duration of the drain back (15 minutes) divided by the transfer line diameter ( 4 inches).

$$
\left(\left(0.117^{\prime \prime}\right) *(15)\right) / 4^{\prime \prime}=0.66 \text { or } 66 \% \text { rounding up } 70 \%
$$

The above figure was rounded up for purposes of conservatism. This settled solids percentage is very conservative because the calculation process assumes that no solids resuspension occurs due to the flow of liquid over the solids during the drain back process.

Volume of Solids Settled In The Transfer Line - Is equal to the initial solids volume in the transfer line times the percentage which settles out.

$$
(360 \text { gallons }) *(0.70)=250 \text { gallons. }
$$

2. Calculation of the hydrogen generation rate to be expected from the above solids inventory left in the pipeline.

Hydrogen Generation Rate Calculation - The current hydrogen generation in tank C$106 \mathrm{is} 30 \mathrm{ft}^{3} /$ day, Reference 1. The in line hydrogen generation rate is equal to this total hydrogen generation rate times the volume of solids in the transfer line (250 gallons) divided by the volume of solids in tank C-106 (197,000 gallons).

$$
\left(30 \mathrm{ft}^{3} / \text { day }\right) *(250 \text { gal. }) /(197,000 \text { gal. })=\mathbf{0 . 0 3 8} \mathrm{ft}^{3} / \text { day }
$$


HNF-SD-W320-ANAL-004, Rev, 1

3. Calculation time required for the above hydrogen generation rate to achieve hydrogen concentration of $25 \%$ of the lower flammability limit in the transfer line assuming no volume exchange with the tank vapor space.

Lower Flammability Limit (LFL) Build-up Duration Calculation - The LFL for hydrogen is $4 \%$. $25 \%$ of that value is $1 \%$. The time required for a $0.038 \mathrm{ft}^{3} /$ day generation rate to build up to $1 \%$ of the volume $\left(1200 \mathrm{gal} . / 7.5 \mathrm{gal} . / \mathrm{ft}^{3}=160 \mathrm{ft}^{3}\right)$ of the transfer line is calculated below.

$$
\begin{aligned}
& \mathrm{t}=-(\mathrm{vol} / \mathrm{g}+\mathrm{v})) *\left(\ln \left[1-\left(\% \mathrm{H}_{2} / 100\right) *(\mathrm{~g}+\mathrm{v}) / \mathrm{g}\right]\right) \\
& \text { where vol }=\text { pipe volume }\left(160 \mathrm{ft}^{3}\right) \\
& \mathrm{g}=\mathrm{H}_{2} \text { generation rate }\left(0.038 \mathrm{ft}^{3} / \text { day }\right) \\
& \mathrm{v}=\text { pipe ventilation rate }\left(0 \mathrm{ft}^{3} / \text { day }\right) \\
& \% \mathrm{H}_{2}=25 \% \text { LFL }\left(1 \% \mathrm{H}_{2}\right) \\
& t \quad t=-\frac{160}{0.038+0} * \ln \left(1-\frac{1}{100} * \frac{0.038+0}{0.038}\right)
\end{aligned}
$$

The above LFL build up calculation is rounded down for reasons of conservatism.

Flushing Fluid Determination - This determination evaluates the adequacy of utilizing raw water as the flushing media versus utilizing buffered (corrosion inhibited) water.

The use of raw water to flush the stainless steel transfer piping will not produce an unacceptable corrosion rate given the FDC specified two year design life for the transfer line, and the fact that the transfer lines are made of Schedule 40 stainless steel pipe.

The other item to be considered in determining the flush solution is the potential that using raw water has for impacting tank corrosion protection limits.

During the one year active operating life (Reference 5) the worst case number of flushes would be 12 ( 1 per month for 12 months). The total volume of these flushes would be the above calculated 2400 gallon flush volume per transfer line time two for the two transfer lines times 12 the total number of flushes.

$$
(2400 \text { gal. }) *(2) *(12)=57,600 \text { gallons }
$$


The total volume of waste into which this flush volume is added is the volume of waste in tank AY-102 (500,000 gallons minimum) plus the volume that will be transferred from C106 into AY-102 (2 foot of waste or 60,000 gallons).

$$
500 \mathrm{~K} \text { gal. }+60 \mathrm{~K} \text { gal. }=560 \mathrm{~K} \text { gallons }
$$

The percentage of the total waste volume that this worst case flushes could produce is therefore

$$
(57.6 \mathrm{~K} \text { gal. }) /(560 \mathrm{~K} \text { gal. })=10.3 \%
$$

This flush volume figure is extremely conservative because the actual number of flushes which occur during the active operating life of the WRSS is anticipated to be much less than 12.

The uncertainties in the caustic demand associated with dissolution of tank C-106 sludge during the sluicing operations has caused the need for routine sampling during sluicing operations. These process control samples will be used to ensure that the wastes are maintained within corrosion control specifications. If the samples indicate that the wastes in tank AY-102 are approaching the corrosion control limits, the waste composition will be adjusted by the addition of caustic and nitrite to maintain the required waste composition. The sampling of AY-102 tank will be accomplished in accordance with the WRSS Process Control Plan, HNF-SD-WM-PCP-013 (to be issued). It should also be noted that the addition of corrosion inhibiting chemicals has already been proceduralized for tank AY-102. The potential for impacting the corrosion control limits in the tank is, therefore, considered to be incredible.

\section{INPUT DATA -}

\section{Flush Volume Calculation Inputs -}

1. Pipe Radius - Reference 2, W-320 design drawings (4" M-9 Pipe Code, Sch 40 stainless steel pipe) $\sim 2$ " or $0.165 \mathrm{ft}$.

2. Pipeline Length - Reference $2, \mathrm{~W}-320$ pipeline design drawings $\sim 1730 \mathrm{ft}$.

\section{Flushing Frequency Calculation Inputs -}

1. $30 \%$ maximum solids loading in transfer line - from project FDC, WHC-SDW320-FDC-001, Rev. 3

2. Time required for the line to drain (From Reference 3) - 15 minutes 
3. Solids settling rate (From Reference 4) -

- $\quad$ Three samples gave settling rates of $0.32 \mathrm{~cm} / \mathrm{min}$.

- $\quad$ One sample gave a settling rate of $0.84 \mathrm{~cm} / \mathrm{min}$

- The average settling rate is, therefore $=0.45 \mathrm{~cm} / \mathrm{min}=0.177 \mathrm{in} / \mathrm{min}$.

Flushing Fluid Determination Inputs -

1. Primary Pipeline Material - 304L stainless steel (Reference 2, M-9 Pipe Code)

\section{RESULTS -}

Flush Volume Calculation Results - 2,400 Gallons

Flushing Frequency Calculation Results - The flushing of the transfer line should be undertaken any time that pumping operations are shut down for a period of greater than 1 month. This flushing may occur any time between the transfer shutdown and 30 days after that shutdown.

Flushing may also be initiated any time the process control pump flow and pressure data indicate that solids may potentially be building up in the transfer line.

Once the line has been flushed no additional flushing is required until after active pumping operations have been resumed.

Flushing Fluid Determination Results - Raw water may be used to perform the above flushing operations.

CONCLUSIONS - The objectives of this calculation have been completely met. The methodology and results of this calculation are appropriate for use in the WRSS operations.

\section{REFERENCES -}

1. WHC-SD-W320-SP-002, Rev. 0, Project W-320 Position Paper - Flammable Gas Issue

2. W-320 Pipeline Design Drawings - H-2-818518, ..520, ...533, ...534, and ...540.

3. W320-27-045, "Pipe Drain Flow and Anti-syphon Sizing", FDNW calculation. 
HNF-SD-W320-ANAL-004, Rev. 1

4. WHC-SD-WM-TI-756, Rev. 1, "Chemical and Chemically-Related Considerations Associated with Sluicing Tank C-106 Waste to Tank AY-102," H. Babad, et.al., October 10, 1996.

5. WHC-SD-W320-FDC-001, Rev. 4, "Functional Design Criteria for Tank 241-C-106 Waste Retrieval, Project W-320," J.W. Bailey, June 26, 1997. 